\title{
The Tenth Amendment and Local Government
}

David J. Barron, A Localist Critique of the New Federalism, 51 DuKE L.J. 377 (2001).

It is no historical accident that the "town meeting" is the dominant political metaphor of our American republic. Since the earliest settlers arrived in the New World, towns and cities have been a wellspring of popular sovereignty and civic republicanism. It is a strikingly odd textual fact, then, that localities receive no mention in the Constitution. The document does not specifically define the role that towns and cities play in the constitutional regime, nor does it explicitly preserve a sphere for local autonomy. Given this omission, Supreme Court doctrine and modern scholarship on local government articulate-or at least accept-the following principle: Localities possess no constitutional personality. Local government theorist David Barron's recent meditation on the linkages between local, state, and federal jurisdictions largely reflects the conventional wisdom, at least with regard to this specific legal formality.'

Barron criticizes the Court's emphasis on federalism from a localist perspective. His general argument is that the current "federalism revival" improperly ignores the various ways in which existing "centrally created legal regime[s]" limit local autonomy, ${ }^{2}$ and the various ways in which new regimes-the commandeering systems in Printz ${ }^{3}$ and New York, ${ }^{4}$ for example-may counterintuitively enhance local autonomy. The Court misunderstands the effects of new federal laws, he contends, because it has not properly assessed the place of localities in a broader state and federal structure of governance. ${ }^{5}$

As part of his analysis, Barron tells the standard story-that cities and towns have no explicit constitutional authority to exercise powers other than those granted by the state. ${ }^{6}$ However, he continues, "[I]t is widely

1. David J. Barron, A Localist Critique of the New Federalism, 51 DUKE L.J. 377, 390 (2001) ("As a formal legal matter, the federal Constitution does not treat local governments as anything approximating coequal sovereigns.").

2. Id. at 380 .

3. Printz v. United States, 521 U.S. 898 (1997).

4. New York v. United States, 505 U.S. 144 (1992).

5. See Barron, supra note 1 , at 378-79.

6. Id. at 390-91. 
perceived that, under state law, local governments enjoy a great degree of what is termed local autonomy under state law." While there is no constitutional mandate for local self-determination-that is, the right of citizens to organize local government as they see fit-political realities are such that "any effort by the state to limit [local powers] is understood as a direct threat to local autonomy." committed to "local control," state governments find it difficult to reassert their authority. Thus, concludes Barron, local autonomy is alive and well.

Barron's practical diagnosis may ultimately prove correct, but his rather passive defense of robust localism is cause for concern. We cannot be satisfied with his reliance on emerging state custom to conclude that local self-determination is a safe and protected principle. As a formal matter, localities can be created, destroyed, and reorganized at the whim of the state. ${ }^{9}$ As a practical matter, many states have created annexation procedures without local consent; in fact, the issue of annexation remains hotly contested in communities around the country. ${ }^{10}$ And as a constitutional matter, individual citizens presently possess no cognizable right to determine the scope and structure of their local government, except through their votes for the state legislature. Very few modern scholars seriously question the legal maxim that the Constitution is silent about cities. "Many, like Barron in this article, marginalize the self-determination concern by arguing that it does not present grave problems in practice.

A more affirmative constitutional rationale deserves consideration. This Comment posits that the Constitution may well carve out a limited space for the people to express themselves and exercise certain powers through local self-government-without interference by the state. More specifically, the Tenth Amendment endows the people with the right to choose and define their local government. To defend this claim, the balance of this Comment

7. $I d$ at 393 .

8. Id. at 397.

9. Hunter v. City of Pittsburgh, 207 U.S. 161, 178 (1907) (holding that localities are no more than "convenient agencies for exercising such of the governmental powers of the State as may be entrusted to them").

10. Over the past two decades, several lower courts have considered annexation initiatives, rigidly adhering to the principles of Hunter and applying that case's basic constitutional axiom. See Jordan v. Town of Morningside, 30 Fed. Appx. 144 (4th Cir. 2002); Morgan v. City of Florissant, 147 F.3d 772 (8th Cir. 1998); Hussey v. City of Portland, 64 F.3d 1260, 1263 (9th Cir. 1995); Carlyn v. City of Akron, 726 F.2d 287, 289 (6th Cir. 1984).

11. Interestingly, Barron is perhaps the most creative scholar attempting to articulate some form of local constitutionalism. In an earlier piece, Barron argued that "local governmental sovereignty... merits federal constitutional protection when such recognition would serve some independent substantive constitutional value." David J. Barron, The Promise of Cooley's City: Traces of Local Constitutionalism, 147 U. PA. L. REV. 487, 600 (1999). However, he almost entirely ignored annexation and did not substantially address local self-determination. By contrast, throughout the late nineteenth century, a significant number of scholars and judges subscribed to the view that towns and cities retained a right to self-government under the Constitution. See, e.g., Amasa M. Eaton, The Right to Local Self-Government, 13 HARV. L. REV. 441 (1900). 
is divided into three Parts. Part I will offer a robust vision of the Tenth Amendment, laying the groundwork for locating localism in the text of the Constitution. Part II will then link the Tenth Amendment's commands with the right to local self-determination. Part III concludes.

A caveat before proceeding: This Comment does not seek to provide a comprehensive account of local self-determination, nor a conclusive determination of the Tenth Amendment's relevance for robust localism. On offer here instead is a plausible reading of the Constitution, a brief exploration of that reading, and an invitation for further study and debate. In short, this Comment seeks to start a conversation, not to conclude one.

The Tenth Amendment does not specifically mention localities or local self-determination, or anything else in particular. It contains a single, sweeping pronouncement: "Powers not delegated to the United States by the Constitution, nor prohibited by it to the States, are reserved to the States respectively, or to the people."12 This last phrase, "or to the people," is a constitutional orphan; the Supreme Court has cited the Tenth Amendment in a parade of recent federalism decisions without ever stopping to consider the potential complications posed by its final clause. Court majorities consistently ignore the reference to "the people" and enshrine the reference to the states in concluding that, at its heart, "the Tenth Amendment reserves a zone of activity to the states for their exclusive control."13

A narrow focus on the binary relationship between federal and state governments ignores the elephant in the room. "Or to the people" is not merely surplusage - that much seems clear. The final clause of the Bill of Rights tells us something about the structure of our republican government. As Akhil Amar notes, the document's repeated references to "the people" voice a deeper structural commitment to popular sovereignty. ${ }^{14}$

The Tenth Amendment plays a key role in effectuating this constitutional pledge of popular sovereignty. The provision limits not only powers of the federal government, but the state government as well. This, itself, is not a novel interpretation. Writing in 1962, Norman Redlich argued

12. U.S. CONST. amend. $X$.

13. ERWIN CHEMERINSKY, CONSTITUTIONAL LAW: PRINCIPLES AND POLICIES 227 (1997). These cases include Alden v. Maine, 527 U.S. 706 (1999), Printz v. United States, 521 U.S. 898 (1997), and New York v. United States, 505 U.S. 144 (1992).

14. Akhil Reed Amar, The Central Meaning of Republican Government: Popular Sovereignty, Majority Rule, and the Denominator Problem, 65 U. COLO. L. REv. 749 (1994). Amar ultimately adopts a much narrower interpretation of the Tenth Amendment than that proffered here: He argues that the people, distinct from the states, are empowered to alter and abolish the government. AKHIL REED AMAR, BILL OF RIGHTS: CREATION AND RECONSTRUCTION 121 (1998). This Comment seeks not to refute that claim-indeed, I agree with Amar on this point - but rather to expand the grant of popular sovereignty implicit in the Tenth Amendment. 
that the closing phrase of the Tenth Amendment identified a collection of powers "possessed by neither the federal government nor the states." 15

The framing history of the provision supports this structural account. Most importantly, the amendment eventually ratified by the states "was not the same amendment Madison described as purely declaratory of the original federal design." ${ }^{\text {"6 }}$ Madison's original Tenth Amendment proposal stated, "The powers not delegated by this constitution, nor prohibited by it to the states, are reserved to the states respectively." "17 But the Senate opted not to accept Madison's wording in toto by voice vote, the chamber added the words "or to the people" to the Amendment. ${ }^{18}$ The Senate sought to express a simple principle through the addition of this phrase. This principle proffers that certain powers "reserved ... to the people" belong to neither the federal government nor the state government.

State participation in the design and wording of the Tenth Amendment indicates that this principle held sway beyond the Senate chamber. Each of the states contemplating ratification of the Bill of Rights had offered its own version of the Tenth Amendment, and many of these proposals expressed similar principles to that enshrined in the final version. For example, the New York proposal supports the interpretation that the people and the states are distinct entities, each claiming certain powers. ${ }^{19}$ The New York language highlights the importance of the conjunction "or" in the Tenth Amendment. Rather than reserving powers to the states and the people, thus making those powers coextensive, the Amendment distinguishes between the two. By contrast, Virginia's offering omitted any mention of the people, focusing entirely on states' rights. ${ }^{20}$ But the New

15. Noman Redlich, Are There "Certain Rights . . Retained by the People?," 37 N.Y.U. L. REV. 787, 807 (1962). He contends that the cxistence of unenumerated rights in the Ninth and Tenth Amendments implies that certain powers are held by neither government. Id. But see Thomas B. McAffee, Federalism and the Protection of Rights: The Modern Ninth Amendment's Spreading Confusion, 1996 BYU L. REV. 351, 358 (arguing that the Tenth Amendment is nothing more than a reaffirmation of enumerated powers, and rejecting the Redlich view because it "rests on pure speculation" and defies the "text and history of the Tenth Amendment").

16. McAffee, supra note 15 , at 357.

17. James Madison, Debates in the House of Representatives (June 8, 1789), reprinted in CREATING THE BILL OF RIGHTS: THE DOCUMENTARY RECORD FROM THE FIRST FEDERAL CONGRESS 11, 14 (Helen E. Veit ct al. cds., 1991) [hereinafter CREATING THE BILL OF RIGHTS] (emphasis added).

18. House Resolution and Articles of Amendment (Aug. 24, 1789), reprinted in id. at 37, 41 n.23. The Senate added "or to the people" on September 7, 1789. Id.

19. The New York ratification convention set forth the following proposal:

That every Power, Jurisdiction, and right, which is not by the said Constitution clearly delegated to the Congress of the United States, or the departments of the Government thereof, remains to the people of the several States, or to their respective State Governments to whom they may have granted the same....

New York Proposed Amendments (1788), reprinted in 2 THE BILL OF RIGHTS: A DOCUMENTARY HISTORY 911, 911-12 (Bernard Schwartz ed., 1971).

20. Amendments Proposed by the Virginia Convention (June 27, 1788), reprinted in CREATING THE BILL OF RIGHTS, supra note 17, at 17, 19. 
York view ultimately won the day. The implicit debate among the states, like the explicit debate on the Senate and House floors, reveals the meaningful distinction between a Tenth Amendment vision of states' rights and a Tenth Amendment vision of popular sovereignty that reserves certain powers to the people as a distinct locus of that sovereignty. ${ }^{21}$

In addition to the plain textual and historical evidence, arguments that sound in constitutional structure also militate in favor of reading the Tenth Amendment as reserving certain powers to the people. The structure of the document begins by proclaiming that "We the People" collectively establish the Constitution, and consistently refers to the rights of the people throughout. $^{22}$ The Tenth Amendment, viewed against this backdrop, expresses "a triangular relationship among the federal government, state governments, and the people."23

This Part posits that the Tenth Amendment's reservation of certain powers to the people is at the same time a reservation of certain powers to local government. And as the provision implicitly authorizes the people to express their will through local communities, it consequently demands that they freely choose the organization of their town or city government. In this way, the Tenth Amendment grants the right of local self-determination. ${ }^{24}$ Of course, to justify this expansive reading, one must articulate a constitutional rationale for why localities in particular should serve as the vehicle through which the people exercise their reserved powers. ${ }^{25}$ Such a rationale can be found in the history of colonial localism, in the structure of the Constitution, and ultimately in the text of the Tenth Amendment.

History supports this Comment's constitutional intuitions: Towns, townships, and cities have always represented an important locus of popular sovereignty. The American historical experience with local government

21. This Comment's interpretation of the Tenth Amendment draws further support from the Asticles of Confederation, which make no mention of "the people": "Each state retains its sovereignty, freedom and independence, and every Power, Jurisdiction and right, which is not by this confederation expressly delegated to the United States..." ARTICLES OF CONFEDERATION art. II. The Constitution's various references to "the people" thus possess greater significance.

22. For a structural interpretation of the Tenth Amendment, see Kathryn Abrams, Note, On Reading and Using the Tenth Amendment, 93 YALE L.J. 723, 730-31 (1984). See also text accompanying note 14 (discussing Amar's structural observations about references to "the people").

23. Jay S. Bybee, The Tenth Amendment Among the Shadows: On Reading the Constitution in Plato's Cave, 23 HARV. J.L. \& PUB. POL'Y 551, 565 (2000).

24. Put another way, if states could simply draw local government boundaries as they saw fit, the powers of local govemment would evaporate altogether. As we have seen, the Tenth Amendment does not permit such an outcome.

25. Such a rationale does not require that local government be the only mechanism through which the people exercise their powers. See supra note 15. 
yields important lessons for our modern understanding of the Tenth Amendment's commands. Early American towns formed the foundation of colonies, particularly in New England. The communities of Portsmouth, Providence, Newport, and Warwick, for example, united to form the colony of Rhode Island. ${ }^{26}$ These towns remained potent political actors after colonial formation: Legislative bodies throughout New England were composed of delegates dispatched by towns to represent local interests. ${ }^{27}$

Similarly, in colonial Maryland, "a representative... would stand for the whole community," casting "a single vote in the assembly.," And the 1776 constitutions of Virginia and North Carolina "provided for an assembly composed of two representatives from every county, and one from each city or borough. ${ }^{, 29}$ New York City-one of the only major colonial cities-represented a powerful locus of political sovereignty, demanding a substantial measure of local autonomy from the colony and subsequent state of New York. ${ }^{30}$ And contemporaneous political theory tracked early American history. Localities were viewed as "little republics," repositories of popular sovereignty through which citizens decided the most fundamental political questions. ${ }^{31}$

When colonies became states, "corporate" representation-whereby representatives were allotted to towns-began to give way to proportional, one-person-one-vote, representation. While small states generally retained a

26. ANWAR HusSan SYED, THE POLITICAL THEORY OF AMERICAN LOCAL GOVERNMENT 22-24 (1966).

27. For example, Vermont's 1777 Constitution "allocated one representative to each town in the state." James A. Gardner, One Person, One Vote and the Possibility of Political Community, 80 N.C. L. REV. 1237, 1245 (2002); see also ERNEST S. GRIFFITH, HISTORY OF AMERICAN CITY GOVERNMENT: THE COLONIAL PERIOD 334-40 (1938) (discussing the separate representation of cities and towns in colonial assemblies). As one scholar put it, "Historians disagree on when towns played a predominant role in New England, not on whether towns ever functioned as a major political institution." Joan C. Williams, The Invention of the Municipal Corporation: A Case Study in Legal Change, 34 AM. U. L. REV. 369, 410-11 (1985).

28. EDMUND S. MORGAN, INVENTING THE PEOPLE: THE RISE OF POPULAR SOVEREIGNTY IN ENGLAND AND AMERICA 40 (1988).

29. Gardner, supra note 27 , at 1245.

30. In the early 1680 s, citizens of New York City and towns throughout the state insisted on the adoption of an English model, under which local government exercised certain powers free from central colonial interference. Nicholas Varga, The Development and Structure of Local Government in Colonial New York, in TOWN AND COUNTY: ESSAYS ON THE STRUCTURE Of LoCAl GOVERNMENT IN THE AMERICAN Colonies 194 (Bruce C. Daniels ed., 1978). Even as New York moved away from the corporate model, the postindependence New York State Constitution of 1777 mandated the preservation of the city charter, ensuring that New York City would be "protected from intrusions by its new sovereign." Williams, supra note 27, at 395.

31. Thomas Jefferson, an eloquent exponent of the view that sovereignty ultimately rests with the people, imagined a tiered structure of government that deposited substantial authority at the local level. Richard Briffault, Our Localism: Part II-Localism and Legal Theory, 90 CoLUM. L. REV. 346, 416 (1990). Tocqueville shared Jefferson's enthusiasm for local government. On his view, state and federal governments existed only because the people, through "local assemblies of sovereign individuals[,] empowered them." Joseph P. Viteritti, Municipal Home Rule and the Conditions of Justifiable Secession, 23 FORDHAM URB. L.J. 1, 9 (1995). 
corporate model, many larger states opted to "implement numerical apportionment in their legislatures." 32 Over time, the individual ultimately became the standard unit of voting power for state assemblies. But, Rosemaric Zagarri hastens to note, the Constitution "embodied the principles of both corporate and proportional apportionment, spatial and demographic representation." ${ }^{\text {"33 }}$ This suggests that the Framers were prepared to preserve some political sovereignty at the local level, even as they anticipated the ascendancy of the individual in state elections.

This historical evidence informs a structural and textual account of the Tenth Amendment that makes way for constitutional localism. Structurally, our constitutional framework presupposed the existence of cities and towns as important political communities through which the people expressed their will and exercised various powers. ${ }^{34}$ In the Framers' general allocation of rights and powers, then, local political communities stood apart from states and the federal government as a third layer of government. This argument builds on the observations of Judge Thomas Cooley, a passionate defender of localities as constitutional actors. On Cooley's view, "[T]he constitution [was] adopted in view of a system of local government, well understood and tolerably uniform in character, existing from the very earliest settlement of the country. [T] he liberties of the people [were] generally... supposed to spring from, and be dependent upon that system. .35

Cooley's observation links up nicely with a textual Tenth Amendment argument. The Framers like their English forebears-chicfly operated in local political communities; they formed units and subunits to carry out governmental functions and resolve political disputes. Thus, "the people" described in the Constitution are not atomized individuals, but "people living together in particular communities." ${ }^{36}$ And these are the same people endowed with powers by the Tenth Amendment.

Ultimately, localities play a key role in the "triangular relationship" among the federal government, state government, and the people. That the people reserve certain powers distinct from the states and the federal government is a direct, explicit lesson of the Tenth Amendment; that they exercise them through local government is an indirect, implicit lesson of

32. Rosemarie Zagarri, The Politics of Size: RePREsentation IN THE UNited States, $1776-1850$, at 60 (1987).

33. Id. at 149.

34. See Richard Briffault, Our Localism: Part I-the Structure of Local Government Law, 90 CoIUM. L. REV. 1, 89 (1990) (noting that the Court, in key decisions, has "recognize[d] the 'universal' existence of local governments possessing considerable autonomy and providing an important representational function"').

35. People v. Hurlbut, 24 Mich. 44, 98 (1871) (emphasis added).

36. David J. Barron, The Promise of Cooley's City: Traces of Local Constitutionalism, 147 U. PA. L. REV. 487, 516 (1999). 
constitutional design. Text, history, and structure demonstrate that the Constitution reserves, to the people, the power to design their own local governments and draw their own local political boundaries.

Establishing this constitutional point, however, begs perhaps an even bigger question: Which powers does the Constitution reserve to local government? In what contexts does the document protect localities from state interference? Accepting that the role of local government has changed dramatically in the modern era, how can we properly update our understanding of local self-determination? To address these questions adequately is to embark on a new inquiry, involving new tools and sources. Such an endeavor is beyond the scope of this Comment.

III

What is clear is that the right to local self-determination opens the way to a more robust understanding of localism. If we heeded the Tenth Amendment's imperative that citizens consensually design their local political communities, these same citizens could cast votes at both the local and state levels with an eye toward the proper allocation of powers between them. They could more meaningfully participate in statewide debates on the structure of home-rule statutes, knowing the strengths and weaknesses of their local government, and knowing that state government could not redesign or eliminate their local political community. Most importantly, such a reading of the Tenth Amendment would signal the end of nonconsensual annexation, and would appropriately ensure that the people control this third layer of sovereignty.

These are no small stakes. If scholars like Barron more thoroughly problematize the apparent lack of constitutional personality for cities, they might come to recognize the deep structural meaning of the Tenth Amendment, and, in turn, the constitutional importance of popular sovereignty at the local level. In so doing, the academy will be well positioned to articulate a new constitutional vision of local government. This vision would be an important conceptual contribution to the constitutional canon, and would also address important practical questions of local government funding and local government police powers. ${ }^{37}$ For now, the people must settle for evolving state practice-rather than constitutional mandate - to protect the elusive, if not illusory, right to local self-determination.

-Jake Sullivan

37. Barron, supra note 1, at $394-96$. 